\title{
Neuropilin-1 expressing melanoma cells as a model to study the aggressiveness of metastatic melanoma
}

\author{
Federica Ruffini ${ }^{1}$, Grazia Graziani ${ }^{2}$, Lauretta Levati ${ }^{3}$, Lucio Tentori ${ }^{2}$, Simona Caporali ${ }^{1}$, Stefania D'Atri ${ }^{1}$, \\ Pedro M Lacal ${ }^{1 *}$
}

From Melanoma Bridge Meeting 2014

Naples, Italy. 03-06 December 2014

\section{Background}

The molecular mechanisms associated with the acquisition of a metastatic phenotype by melanoma cells are not very well understood. Therefore, the identification of molecular determinants involved in the metastatic switch that may either cause or contribute to the aggressiveness of melanoma is of primary relevance.

We had previously identified neuropilin-1 (NRP-1), a co-receptor of the vascular endothelial growth factor-A (VEGF-A), as an important determinant of melanoma aggressiveness, in clones of the human melanoma cell line M14, expressing or not NRP-1 [1,2]. We demonstrated that even though the simultaneous presence of both VEGFR-2 and NRP-1 potentiates VEGF-A secretion and the aggressiveness of melanoma cells, NRP-1 is by itself able to promote cell invasion [1].

During melanoma progression, tumour cells show increased adhesiveness to the vascular wall, invade the extracellular matrix (ECM) and frequently form functional channels similar to vascular vessels (vasculogenic mimicry) [3]. In the present study we analysed the mechanisms responsible for the aggressive phenotype of NRP-1 expressing melanoma cells.

\section{Materials and methods}

Melanoma aggressiveness was evaluated in vitro as cell ability to migrate through an ECM layer in Boyden chambers and to form tubule-like structures on matrigel gels. Pre-incubation of the cells with specific blocking antibodies allowed the identification of specific integrins and other molecules relevant to these processes. The

'Laboratory of Molecular Oncology, "Istituto Dermopatico dell'Immacolata"IRCCS, Rome, Italy

Full list of author information is available at the end of the article results obtained by anti-integrin antibodies, showing the involvement of $\alpha v \beta 5$ integrin in the aggressiveness of melanoma cells expressing NRP-1, were confirmed by ITGB5 gene silencing and by the use of cilengitide, a potent inhibitor of $\alpha v$ integrins activation.

\section{Results}

The expression of $\alpha \mathrm{v} \beta 5$ integrin was found to be twice higher in NRP-1 expressing melanoma cells than in the low-invasive NRP-1 negative control. Its blockage resulted in a significant decrease of the ability of NRP-1 expressing cells to invade ECM and to form tubule-like structures on matrigel. Cilengitide and ITGB5 silencing reduced ECM invasion and vasculogenic mimicry. Moreover, cilengitide down-modulated the secretion of VEGF-A and metalloproteinase-9 (MMP-9). Finally, melanoma cells expressing NRP1, but lacking other VEGF-A or PlGF receptors (VEGFR-1 and VEGFR-2), specifically responded to PIGF in a chemotactic assay.

\section{Conclusions}

In conclusion, we identified novel mechanisms that modulate melanoma aggressiveness involving NRP-1, $\alpha v \beta 5$ integrin and PIGF, which might be considered as new targets of therapeutic strategies to inhibit the metastatic disease.

\section{Acknowledgment}

Supported by the Italian Ministry of Health (RC14-3.3) and by the

"Associazione Italiana per la Ricerca sul Cancro" (AIRC 2013 IG 14042)

\section{Authors' details}

'Laboratory of Molecular Oncology, "Istituto Dermopatico dell'Immacolata"IRCCS, Rome, Italy. ${ }^{2}$ Department of Systems Medicine, University of Rome 
"Tor Vergata", Rome, Italy. ${ }^{3}$ Clinical Epidemiology Unit, "Istituto Dermopatico dell'Immacolata"-IRCCS, Rome, Italy.

Published: 15 January 2015

\section{References}

1. Ruffini F, D'Atri S, Lacal PM: Neuropilin-1 expression promotes invasiveness of melanoma cells through vascular endothelial growth factor receptor-2 dependent and independent mechanisms. Int $J$ Oncol 2013, 43:297-306.

2. Ruffini F, Tentori L, Dorio AS, Arcelli D, D'Amati G, D'Atri S, Graziani G, Lacal PM: Platelet derived growth factor $C$ and calpain-3 are modulators of human melanoma cell invasiveness. Oncol Rep 2013, 30:2887-2896.

3. Seftor RE, Hess AR, Seftor EA, Kirschmann DA, Hardy KM, Margaryan NV, Hendrix MJ: Tumor cell vasculogenic mimicry: from controversy to therapeutic promise. Am J Pathol 2012, 181:1115-1125.

doi:10.1186/1479-5876-13-S1-P6

Cite this article as: Ruffini et al:: Neuropilin-1 expressing melanoma cells as a model to study the aggressiveness of metastatic melanoma.

Journal of Translational Medicine 2015 13(Suppl 1):P6.

\section{Submit your next manuscript to BioMed Central} and take full advantage of:

- Convenient online submission

- Thorough peer review

- No space constraints or color figure charges

- Immediate publication on acceptance

- Inclusion in PubMed, CAS, Scopus and Google Scholar

- Research which is freely available for redistribution

Submit your manuscript at www.biomedcentral.com/submit 